ANNA HŁUSZKO

ORCID: 0000-0001-5054-6499

Katedra Dziennikarstwa

Doniecki Uniwersytet Narodowy im. Wasyla Stusa w Winnicy

\title{
Wstrząsająca treść jako manipulacyjny element dyskursu konfliktu
}

\section{Abstrakt}

Trudna sytuacja społeczno-polityczna na Ukrainie tworzy specyficzny dyskurs medialny, który z kolei zapoczątkowuje ciąg zjawisk powiązanych z kategoriami wojny informacyjnej, wojny znaczeń, jak i mowy nienawiści. Aktywne wdrażanie tematyki wojennej w zawartość serwisów informacyjnych wpływa na tradycyjne podejście do konstruowania tekstu medialnego.

W niniejszym tekście przeanalizowano tendencje do wykorzystywania szokujących treści wizualnych i anonsowania ich w nagłówkach internetowych serwisów informacyjnych. Zbadano również, jak emocjonalizacja treści, będąca jednym z typowych zjawisk dyskursu konfliktu, wpływa nie tylko na stylistykę tekstów, ale i cechy ich wersji roboczej, wybór i wykorzystanie zdjęć opatrujących tekst, tworzenie nagłówków. Materiały poświęcone działaniom wojennym zazwyczaj wiążą się z informacjami o śmierci, odniesionych ranach, stratach, zrujnowaniu terenów zabudowanych wskutek akcji zbrojnych, skupiają się więc na wiadomościach o cierpieniu zarówno żołnierzy, jak i cywili. Efektem tego jest intensywne wplatanie w zawartość szokujących treści wizualnych, które z kolei może posłużyć jako narzędzie manipulacji i propagandy. Z jednej strony wykorzystuje się je w celu ukazania zbrodni wroga, z drugiej zaś jako dowód sukcesów ukraińskich żołnierzy. Zasadność użycia takiego narzędzia z punktu widzenia etyki oraz humanizmu jest wątpliwe w obu wypadkach. Rezultaty badań natomiast świadczą o tym, że występowanie wyrazistych obrazów krwi, śmierci, obrażeń oraz upowszechnianie tego typu treści w nagłówkach jest głównym czynnikiem dużej popularności takich publikacji. To czyni aktualnym problem dehumanizującego wpływu materiału w odniesieniu nie tylko do jego bohaterów, lecz także odbiorców.

Słowa kluczowe: konflikt, emocjonalizacja, nagłówek, manipulacja.

Skomplikowana sytuacja społeczno-polityczne na Ukrainie wpływa na kształt dyskursu medialnego. Powoduje nasilenie się w nim nowych zjawisk powiązanych z językiem agresji, kategoriami wojny informacyjnej i wojny sensów. Nagminne wykorzystywanie tematyki rosyjsko-ukraińskiego konfliktu zbrojnego wpływa na 
podejście reporterów wojennych do konstruowania tekstu medialnego, aktualizuje kwestie celowości, etyczności, równowagi oraz bezstronności środków masowego komunikowania się.

Obecnie jednym z typowych zjawisk dyskursu konfliktu (kryzysu komunikacyjnego w sieci) jest nadużywanie szokujących materiałów fotograficznych eksponujących ludzkie cierpienia, a nawet ofiary wypadków, katastrof, aktów terrorystycznych itp. W ukraińskiej praktyce medialnej tendencja ta nasiliła się podczas konfliktu zbrojnego lat 2014-2017. Najwyraźniej zostało to wyeksponowane w serwisach informacyjnych umieszczanych w sieci internetowej, co tłumaczy się swoistymi granicami etyki, właściwymi dla Internetu (w porównaniu do mediów drukowanych lub telewizyjnych). Wysoki stopień dynamiczności i duża zmienność komunikatów, większa swoboda wyrażania myśli, nieprecyzyjnie określone zasady etyki dziennikarskiej, duża konkurencja - to wszystko zachęca środki masowego przekazu do poszukiwania coraz nowszych narzędzi przyciągania uwagi oraz poszerzenia grona odbiorców.

Specyfika współczesnych mass mediów umożliwia publikację dużej liczby zdjęć dokumentalnych wysokiej jakości oraz włączenie nagrań wideo do materiałów tekstowych. Portale informacyjne prześcigają się w tym, kto pierwszy poda materiały z miejsca konfliktu, kto zaproponuje odbiorcom wyjątkowo wstrząsający obraz. Duża częstotliwość oraz częstość prezentowanych materiałów dziennikarskich związanych ze śmiercią, cierpieniem, uszkodzeniami ciała i ranami odniesionymi w czasie wojny sprawia, że odbiorcy przyzwyczajają się do takich obrazów, a to czyni ich bardziej obojętnymi, powoduje, że zmienia się ich wrażliwość na przemoc.

Celem niniejszego artykułu jest ukazanie tendencji w stosowaniu wstrząsających treści we współczesnych mass mediach na przykładzie nagłówków internetowych serwisów informacyjnych oraz fotoreportaży dotyczących rosyjsko-ukraińskiego konfliktu zbrojnego. Jest to również próba zwrócenia uwagi, że stanowią one element manipulacji, chętnie wykorzystywany przez fotoreporterów wojennych, a nie służą informowaniu społeczeństwa ukraińskiego o bieżącej sytuacji.

Badaniu poddano materiał dokumentacyjny dotyczący wojny rosyjsko-ukraińskiej, który ukazywał się od czerwca 2014 do lutego 2017 roku. Został on wyekscerpowany z serwisów internetowych: dwóch bardzo popularnych — cenzor.net i obozrevatel.com, a także z kilku mniej znanych - newsonline24.com.ua, radio24.ua, ubr.ua, news-ukraine.com, ukr-space.com, inforesist.org, depo.ua, uainfo.org, w których można zauważyć podobne tendencje tworzenia nagłówków informacyjnych.

Od 2014 roku w ukraińskich mediach wśród wszystkich tematów pierwsze miejsce zajmuje wojna rosyjsko-ukraińska - na przykład cenzor.net codziennie publikuje prawie dwieście informacji, których większość usystematyzowana jest według tematów: „Operacja antyterrorystyczna”, „Agresja Rosji przeciwko Ukrainie”, „Dywersanci na wschodzie Ukrainy”, „Wolontariusze dla wojska”, „Bitwa o lotnisko w Doniecku". Według moich obliczeń w latach 2014-2015 materiały te stanowiły 50-65\% ogólnej objętości bloku informacyjnego, z kolei w 2016 i 2017 roku wy- 
nosiły one od 25 do $35 \%$. Procentowy udział publikacji nie wpłynął na mniejsze zainteresowanie wojną - popularność wiadomości o konflikcie jest bardzo duża i wynosi od 100 do 150 tys. wejść, czasami nawet więcej.

W wyniku przeprowadzonej analizy zostały wyróżnione tendencje, które są przedmiotem niniejszego opracowania.

\section{Niczym nieusprawiedliwione, częste nadużywanie wstrząsających zdjęć}

Zdjęcia dokumentalne są nieodłączną częścią nowoczesnego dziennikarstwa, bezcennym źródłem wiarygodnego oraz bezpośredniego przekazu. Niejednokrotnie doświadczenia korespondentów wojskowych na świecie potwierdzają, że takie wstrząsające obrazy bardzo często stają się powodem dyskusji na temat celowości oraz etyczności w przedstawieniach wojny. Tak dzieje się również w wypadku mediów ukraińskich, w których publikowany jest duży odsetek materiałów o toczącym się konflikcie. Odnosi się wrażenie, że chcą one upowszechniać treści (coraz) bardziej szokujące, niż miało to miejsce przed rozpoczęciem wojny, przekraczając granice etyki dziennikarskiej. Simon Balzert - dziennikarz niemiecki, odnosząc się do problemu granicy moralnych zachowań dziennikarzy, zalecał, aby unikać publikowania zdjęć, których celem jest samo przedstawienie szokującego obrazu albo zaprezentowanie go dla rozrywki publiczności. Twierdził, że trzeba szukać możliwości tekstowego opisu informacji zawartej w zdjęciach oraz sprawdzać, czy jest wystarczająco dużo miejsca na stronie nie tylko do publikacji fotografii, ale też dla tekstu z tłumaczeniem i komentarzem. Na podstawie swoich badań wysunął wniosek, że im więcej zdjęć ze scenami przemocy publikuje się w prasie, tym mniejszy jest efekt emocjonalny, który wywołują u odbiorcy (Balzert 2013). Ukraińskie środki masowego przekazu działają odwrotnie: publikują w sieci drastyczne zdjęcia, na których są nie tylko zniszczone całe miejscowości, pogorzeliska, ślady po wybuchach, uszkodzone zakłady pracy itd., lecz również ciężko ranni wojskowi i cywile, części ciał ludzkich, ich narządy wewnętrzne, pokaleczone zwłoki itp. Przekaz emocjonalny takich obrazów jest niezwykle silny, nawet wówczas, gdy publikacji towarzyszy tylko jedna fotografia. Niejednokrotnie jest on spotęgowany przez nagromadzenie w jednym przekazie zdjęć o podobnej treści, ale z dużą liczbą szokujących szczegółów.

Jako przykład może posłużyć seria fotoreportaży poświęcona rozstrzelaniu ludzi na przystanku trolejbusowym w Doniecku 22 stycznia 2015 roku - zginęło wówczas 13 osób, a kilkadziesiąt trafiło do szpitala. Komentowało to wydarzenie wiele źródeł, między innymi censor.net.ua, facty.ua, unian.net, uainfo.org i ine, publikując szczegółowe fotoreportaże. Mimo że większość linków mieściła ostrzeżenia o tym, że treść obrazów jest szokująca, nie udało się znaleźć sensownego uzasadnienia nadużywania tak wstrząsających zdjęć i odpowiedzieć na pytanie o celowość 
takiego postępowania. W drastyczności przekazu przodował censor.net, opatrując serię nagłówkiem: „W Doniecku pocisk trafił w przystanek: są poszkodowani, rosyjskie media informują o 13 ofiarach śmiertelnych. Fotoreportaż + VIDEO"1. Zawierała ona 14 zdjęć, z których aż 9 przedstawiało porozrywane ciała ofiar.

Trzeba podkreślić, iż podobne fotoreportaże wykorzystywano do wizualizacji niemal każdego wydarzenia, w wyniku którego ginęli ludzie, niezależnie od charakteru ofiary - osoby cywilne, pasażerowie samolotu pochodzący z zagranicy, żołnierze Zbrojnych Sił Ukrainy lub przedstawiciele organizacji terrorystycznych. Wstrząsająca treść ilustracyjna zamieniała się w narzędzie propagandy niezależnie od specyfiki prezentowanego wydarzenia: stawała się dowodem przestępstw przeciwnika, miała na celu wywołać u odbiorcy gniew, agresję, złość. Przykładami moga być fotoreportaże: „Specnaz $\mathrm{RF}^{2}$ fotografuje się na tle pokaleczonych ciał ukraińskich żołnierzy i depcze flagę ukraińską. FOTO-reportaż ${ }^{3 ”}$ albo „Trupy najemników rosyjskich w Ilowajsku likwidowane przez batalion Donbas. FOTO-reportaż ${ }^{4}$ lub serie publikacji poświęconych tragedii w miejscowości Wołnowacha ${ }^{5}$ (w wyniku ostrzału rakietowego 30 stycznia 2015 roku zostało zabitych 12 pasażerów autobusu), wydarzeniom w tak zwanym Kotle Ilowajskim ${ }^{6}$ (według oficjalnych danych zginęło 366 żołnierzy ukraińskich), ostrzałowi Kramatorska ${ }^{7} 10$ lutego 2015 roku itd.

\section{Aktywne używanie słów-znaczników (markerów) w nagłówkach zapowiadających szokującą treść}

Treść nagłówka to pierwsza postać interpretacji informacji dokonanej przez autora lub redakcję. Wpływa ona na odbiorcę, do pewnego stopnia przygotowuje go do przyjęcia całego przekazu. Nagłówki nie tylko zawierają krótką informację o materiale - również porządkują go według stopnia ważności, a także ozdabiają stronę oraz rozkładają pożądane akcenty (Шевченко 2004: 388-389). Jedną ze specyficznych cech odbioru informacji sieciowych jest niemożność zobaczenia wszystkich podawanych informacji jednocześnie, jak to tradycyjnie odbywa się przy przeglądaniu źródeł drukowanych. Odbiorca widzi szereg nagłówków, które graficznie

${ }^{1}$ http://www. censor.net.ua (dostęp: 22.01.2015).

2 Specnaz (ros. Спецназ) to potoczna nazwa Wojsk Specjalnego Przeznaczenia Federacji Rosyjskiej (ros. Подразделе́ния специа́льного назначе́ния Росси́йской Федера́ции) - http://pl. wikipedia.org/ wiki/Specnaz) (dostęp: 4.07.2017).

${ }^{3}$ http://www. censor.net.ua (dostęp: 8.09.2014).

${ }^{4} \mathrm{http}: / /$ www. censor.net.ua (dostęp: 23.08.2014).

${ }^{5}$ https://censor.net.ua/news/319731/terroristy_pod_volnovahoyi_obstrelyali_avtobus_s_mirnymi_ jitelyami_10_pogibshih_mvd_obnovleno_videofoto (dostęp: 13.01.2015).

${ }^{6}$ https://censor.net.ua/photo_news/299938/unichtojennye_v_ukraine_rossiyiskie_desantniki_ fotoreportaj (dostęp: 27.08.2014).

7 http://korupciya.com/dhzdhnfnndhudh-dhsndhdhdhndhnnfdhdh-6-dhdhdhdhdhndhn-21ndhudhdhdhdhudh-ndhdhdhudh-18-dhdhzdhcdhz/ (dostęp: 10.02.2015). 
prawie się nie różnią między sobą, z wyjątkiem tych, kiedy najbardziej szokujące wiadomości są wyróżniane pogrubioną czcionką lub czerwonym kolorem albo dodatkowo zawierają niewielkie zdjęcie, które odgrywa rolę piktogramu w większym stopniu niż nośnika wizualnej informacji. $\mathrm{Na}$ ich podstawie użytkownik nie może dowiedzieć się, jaki jest sens całego przekazu, co ogranicza oddziaływanie nadawcy na odbiorcę w mediach społecznościowych.

Obecnie projektanci stron internetowych, autorzy tekstów reklamowych, przedstawiciele marketingu internetowego, dziennikarze itp. opracowują zalecenia oraz doradzają, jak stworzyć „skuteczny nagłówek”, aby efektywnie wypromować tekst. W sieci praktyką stało się wykorzystywanie tak zwanych nagłówków klikanych, czyli takich, które na pewno zwrócą uwagę odbiorcy oraz zachęcą do przejścia do kolejnego linku. Wśród najbardziej popularnych porad dominują propozycje: używanie na początku nagłówka cyfr lub słowa „jak”, stosowanie słów kluczowych, różnego rodzaju list pozwalających szybko przeczytać tekst, na przykład: „10 powodów do tego, żeby...”, „5 sposobów na...”, „12 rzeczy, o których nie znaliście o...” itd., korzystanie z przykuwających uwagę magicznych przymiotników, na przykład: niewiarygodny, zaskakujacy, gwarantowany, lekki itp. (Плетнев 2016), a także włączenia intrygi, obietnic zysku/strat, wezwań do działania itd.

W badanym materiale źródłowym dziennikarze oraz redaktorzy serwisów informacyjnych używają charakterystycznych słów-znaczników (markerów), na przykład imponujące, tragiczne, szokujące, wyjątkowe, nagranie tajne, oraz określeń zapowiadających wizualną treść nagłówka - „Foto”, „Fotoreportaż”, „Wideo”, nieco rzadziej „Infografika”; podaje się także informacje o ograniczeniach w dostępie do informacji, między innymi: wieku „18+”, „ściśle 18” i/lub „niezalecane dla osób niepełnoletnich oraz kobiet w ciąży". W celu wzmocnienia emocjonalności przekazu wykorzystywane są także czasowniki podkreślające agresywne zachowania językowe, między innymi bić, niszczyć, likwidować, katować, zdemolować, rozerwać na kawałki, oraz słowa $\mathrm{z}$ negatywną konotacją, które warunkowo mogą odnosić się do pola semantycznego śmierci, na przykład trupy, ciała, ofiary, umarli, trupiarnia, katowanie, okrucieństwo.

Poniżej podaję przykłady z podziałem na dwie grupy, aby lepiej zobrazować manipulacyjny charakter materiału. Wart podkreślenia jest jeden cel tych publikacji - chęć wywołania szokującego wrażenia na odbiorcy oraz niemal całkowita identyczność w doborze słownictwa w obu zestawieniach, co może wynikać z cynizmu dziennikarzy:

1) Grupa A zawiera nagłówki odnoszące się do sukcesów ukraińskich żołnierzy w strefie konfliktu zbrojnego (wyróżnienia - A.H.):

— „Rozbita kolumna terrorystów rosyjskich na drodze ze Słowiańska. FOTO nie dla osób o słabych nerwach" ;

${ }^{8}$ http://www.censor.net.ua (dostęp: 7.07.2014). 
$18+)^{m 10}$

— „Siły $\mathrm{ATO}^{9}$ zniszczyły żołnierzy sił specjalnych RF z batalionu „Witiaź” - media (Foto

— „Trupiarnia Doniecka 18+ SZOKUJACE WIDEO”"11;

— „Za Wołnowachę!: grupa partyzantów ukraińskich »Cienie« zniszczyła terrorystów. FOTO $18+" 12$;

— „Terroryści zostali rozbici pod Debalcewem — w trupiarniach Doniecka gorąco, - media. FOTO - reportaż 18+" ${ }^{\prime 3}$;

— „Szokujące kadry wojny: Rozerwane trupy terrorystów pod Debalcewem (foto 18+)”14;

- „Jednostka moździerzowa bojowników zniszczona przez bezpośrednie uderzenie ukraińskiej artylerii - szokujące FOTO"15.

2) Grupa B zawiera nagłówki opisujące przestępstwa zbrojnych organizacji terrorystycznych:

— „Okrucieństwa $\mathrm{DNR}^{16}$ w Awdijiwce. Szokujące kadry 18+"17;

— „TOP-3 szokujących wideo ze strefy ATO (18+)"

— „Szokujące wideo z miejsca aktu terrorystycznego w strefie ATO (Ściśle 18+)"19;

— „W Doniecku pocisk trafił w przystanek: są ofiary, rosyjskie media informują o 13 ofiarach śmiertelnych. FOTO-reportaż + WIDEO"20;

— „Zostały ujawnione szczegóły ostrzału osób cywilnych w Doniecku: przerażające zdjęcia i wideo $18+" 21$;

- „Szokujące zdjęcia poranionych ukraińskich żołnierzy wstrząsnęly mediami społecznościowymi 18+"22; $18+" 24$.

- „Jak raszyści ${ }^{23}$ torturują ukraińskich jeńców wojskowych. Szokujące 20-minutowe wideo.

9 ATO - skrót Antyterrorystycznej Operacji wymierzonej przeciwko separatystom, rozpoczętej 13 kwietnia 2014 roku na terenie obwodu donieckiego i ługańskiego.

10 24tv.ua (dostęp: 29.09.2014).

$11 \mathrm{http} / / /$ www.obozrevatel.com (dostęp: 11.10.2014).

12 http://www.censor.net.ua (dostęp: 20.01.2015).

13 http://www.censor.net.ua (dostęp: 29.01.2015).

14 korupciya.com (dostęp: 18.02.2015).

15 http://www.censor.net.ua (dostęp: 26.07.2016).

${ }^{16}$ DNR - skrót od rosyjskiej i ukraińskiej nazwy: Doniecka Republika Ludowa, DRL (ros. Донецкая Народная Республика, Donieckaja Narodnaja Riespublika; ukr. Донецька Народна Республіка, Donećka Narodna Respublika, DNR) - nieuznawane państwo utworzone z części obwodu donieckiego Ukrainy; https://pl.wikipedia.org/wiki/Doniecka_Republika_Ludowa (dostęp: 4.07.2017).

${ }^{17} \mathrm{http} / / /$ inforesist.org (dostęp: 31.07.2014) DNR.

$18 \mathrm{http}: / /$ www.obozrevatel.com (dostęp: 4.08.2014).

${ }^{19} \mathrm{http}: / /$ radio24.ua (dostęp: 13.01.2015).

${ }^{20} \mathrm{http}: / /$ www.censor.net.ua (dostęp: 22.01.2015).

${ }^{21} \mathrm{http}: / /$ www.obozrevatel.com (dostęp: 30.01.2015).

22 news-ukraine.com (dostęp: 14.08.2015).

${ }^{23}$ Raszyści - pogardliwa nazwa separatystów walczących w obwodzie donieckim i ługańskim przeciwko Ukrainie, utworzona $\mathrm{z}$ ang. Russia + -yści.

${ }^{24}$ ukr-space.com (dostęp: 2.01.2016). 


\section{Wykorzystanie słów-znaczników (markerów) \\ w celach reklamowych, a nie tylko jako ostrzeżenie przed szokującymi treściami}

Typowe słowa-znaczniki, na przykład „Foto 18+”, powinny ostrzegać określone grupy odbiorców, chronić je przed szokującymi treściami. Badania udowodniają, że obecność podobnych oznakowań, zwłaszcza w połączeniu ze wspomnianą emocjonalną leksyką, powoduje wprost przeciwny efekt: stymuluje, zachęca do sięgania po wstrząsające fotoreportaże. Ową tendencję potwierdza statystyka. Otóż wiadomość z tego samego dnia i zamieszczona na tym samym portalu ze znacznikiem: „Terroryści zostali rozbici pod Debalcewem - w trupiarniach Doniecka gorąco, - MEDIA. FOTO - reportaż $18+" 25$ miała ponad 278 tys. wejść, natomiast inne wiadomości ze strefy ATO, które nie były opatrzone znacznikiem, miały od 86 do 190 tys. odsłon, czyli średnio 60\% mniej. Najwięcej słów-znaczników zapowiadających szokujące treści pojawiało się w nagłówkach w drugiej połowie 2014 roku oraz w 2015 roku, co należy tłumaczyć szybkością zmieniających się okoliczności, wzmożoną działalnością samych fotoreporterów, ich zaangażowaniem w relacjonowanie konfliktu zbrojnego jako nowego, istotnego dla państwa wydarzenia oraz niebezpiecznego w skutkach dla obywateli, a także chęcią reklamowania siebie - swojej redakcji, portalu itd. poprzez pokazanie czegoś więcej, drastyczniej, dokładniej itp. W 2016 roku wykorzystywano wspomniane znaczniki w znacznie mniejszym stopniu niż na początku wojny rosyjsko-ukraińskiej, być może nie chcąc już potęgować napięcia wśród społeczeństwa ukraińskiego.

\section{Stosowanie nagłówków zawierających prowokacyjne podpowiedzi, wskazujące na szokujące treści}

Niejednokrotnie w nagłówkach umieszczano zachęcające ostrzeżenia o wstrząsającej treści. Był to jednak element manipulacji, ponieważ fotoreportaż zawierał zdjęcia, które nie miały charakteru dokumentacyjnego ani nie były w odbiorze społecznym uznane za szokujące. Podobny zabieg manipulacyjny zastosowano między innymi w następujących przykładach:

— „Separatystka z Mariupola, która prosiła Putina o wprowadzenie wojska, została zabita przez [wyrzutnię] rosyjski »Grad«. FOTO”26;

25 http://www.censor.net.ua (dostęp: 29.01.2015).

${ }^{26} \mathrm{http}: / /$ www.censor.net.ua (dostęp: 25.01.2015). 
$\mathrm{ENR}^{27} 28$

— „Opublikowane przerażające zdjęcia Kirowska zrujnowanego przez ostrzały bojowników

— „Farsz z okupantów: nowa tajna broń ukraińskich żołnierzy. FOTO, WIDEO”29;

— „Snajperzy bojowników zranili dwóch wolontariuszy w strefie ATO: »Stan obu nie jest ciężki«. FOTO (aktualizowane)”30.

Podane nagłówki mogą wywołać u odbiorcy wrażenie, że podane w fotoreportażach treści będą szokować. Okazało się jednak inaczej — treść żadnych z nich nie była wstrząsająca. W ostatnim fotoreportażu pt. „Snajperzy bojowników zranili dwóch wolontariuszy w strefie ATO: Stan obu nie jest ciężki. FOTO (aktualizowane)" mimo że dodana była informacja o aktualizacji materiału, zostało zamieszczone niepodpisane, zatarte, złej jakości zdjęcie, na którym przedstawiono prawdopodobnie jednego ze wspomnianych wolontariuszy, ale przed zdarzeniem, które relacjonowano.

Podsumowując przeprowadzone badania, należy stwierdzić, że w dyskursie konfliktu:

— często nadużywa się drastycznych zdjęć, silnie działając na emocje odbiorców;

- w nagłówkach zapowiadających wstrząsające treści wykorzystuje się charakterystyczne słowa-znaczniki (markery);

- stosuje się nagłówki zawierające prowokacyjne podpowiedzi wskazujące na szokujące treści;

- używa się słów-znaczników (markerów) w celach reklamowych, a nie tylko jako ostrzeżenie przed szokującymi treściami;

- manipuluje się odbiorcą, wykorzystując taką samą lub podobną leksykę ekspresywną do opisania przeciwnych stron konfliktu.

Obecnie zdjęcia dokumentalne, zawierające drastyczne szczegóły w połączeniu ze sposobami emocjonalnego konstruowania nagłówków, stają się środkiem promocji treści medialnych poprzez manipulowanie emocjami oraz przyzwyczajanie odbiorców do coraz bardziej przeraźliwych obrazów. Nadmiar negatywnych przekazów przyczynia się do estetyzacji śmierci i jej komercjalizacji w nowoczesnych mediach sieciowych. Uzasadniony wydaje się postulat niektórych dziennikarzy, aby w ich pracy zawodowej kierować się zasadami etyki dziennikarskiej.

Przełożyła Iryna Procyk

${ }^{27}$ ŁNR - skrót od rosyjskiej i ukraińskiej nazwy Ługańska Republika Ludowa, ŁRL (ros. Луганская Народная Республика, Ługanskaja Narodnaja Riespublika, ŁNR; ukr. Луганська Народна Peспубліка, Łuhanśka Narodna Respublika, ŁNR) - samozwańcza republika działająca na terenie części obwodu ługańskiego Ukrainy; https://pl.wikipedia.org/wiki/\%C5\%81uga\%C5\%84ska_Republika_ Ludowa (dostęp: 4.07.2017).

${ }^{28} \mathrm{http} / / /$ www.obozrevatel.com (dostęp: 1.02.2015).

${ }^{29}$ uainfo.org (dostęp: 28.02.2017).

${ }^{30} \mathrm{http} / / /$ www.censor.net.ua (dostęp: 8.03.17). 


\section{Bibliografia}

Balzert, Simon P. (2013): Leichen auf Seite Eins? Gewaltfotos und Bildethik: deutsche und spanische Qualitätszeitungenim Vergleich. Saarbrücken: AV Akademikerverlag, http://de.ejo-online.eu/qualitaet-ethik/leichen-auf-seite-eins (dostęp: 12.03.2017).

Іванов В. и ин. (2012): Медіаосвіта та медіаграмотність, Київ (http://balakliya-school2.edu.kh.ua/ Files/downloads/\%D0\%9C\%D0\%B5\%D0\%B4\%D1\%96\%D0\%B0\%20\%D0\%BF\%D1\%96\%D0\%B4 \%D1\%80\%D1\%83\%D1\%87\%D0\%BD\%D0\%B8\%D0\%BA.pdf.

Плетнев 3. (2016): 6 советов по написанию заголовков, которые привлекают трафик http:// www.zushipletnev.com/6fishek-zagolovka (dostęp: 15.01.2015).

Почепцов Г. (2015): Сучасні інформаційні війни, Київ.

Шевченко В. (2004): Заголовки як спосіб впливу на суспільну свідомість, „Наукові записки Луганського національного педагогічного університету” У 3-х т., Вип. 5, т. 1, с. 388-397.

\section{Shock content as a manipulative component of conflict discourse}

\section{Summary}

Difficult socio-political situation in Ukraine creates specific media discourse, which in turn gives rise to a number of phenomena, connected to information war categories, war of meanings, hate speech etc. Active entry of military issues into web news content affects traditional approach to the media-text drafting.

The report examines the trends of shock visual content and its announcement in the web headlines. The influence of the content emotionalization, which is one of the common features for conflict discourse, not only on text style, but also on features of page making, selection and use of photo illustrations, headline creation, is studied. The material covering military developments usually involve deaths, injuries, loss, destruction of settlements as a result of hostilities, that is, they focus on information on suffering of both military and civilians. This results in stronger integration of shock visual content into the news, which in turn may be used as manipulation and propaganda tool. On the one hand it is used to demonstrate crimes of the enemy, on the other - as an evidence of Ukrainian military success. From the point of view of ethic and humanism the justification of such tactic is doubtful in both cases. However, the study shows that open image of death, blood, injuries in the materials and the announcement of such content in headlines are the cause of high popularity of such publications, and this mainstreams the problem of dehumanizing impact both on material's subjects and on media audience.

Keywords: conflict, shock content, emotionalization, headline, manipulation. 